\title{
Rival Parkinson's bills focus US debate on fetal tissue
}

Washington. A struggle is developing in the US House of Representatives between two bills that would both substantially boost funding for research on Parkinson's disease, but whose differences highlight the continuing political battle over whether fetal tissue should be used in such research.

One bill, named after former congressman Morris K. Udall, would raise funding by the National Institutes of Health (NIH) to $\$ 100$ million in 1997 , from the current level of $\$ 28$ million, and set up ten Parkinson's disease research centres. The other, introduced by Chris Smith (Republican, New Jersey), is virtually identical but bans federal funding for Parkinson's research using fetal tissue from induced abortions.

NIH officials, led by Harold Varmus, the director, have argued against the Udall bill on the grounds that they could not "responsibly" make use of such a sudden, large increase in Parkinson's research funding, and that generic nerve cell research will produce advances in fighting the disease.

At present, two studies sponsored by the National Institute of Neurological Disorders and Stroke (NINDS) involve transplants of neural tissue from voluntarily aborted fetuses to Parkinson's patients. The studies, at the University of Colorado in Denver and Mount Sinai Medical Center in New York, involve 76 patients and together received \$2.3 million in 1995 .

In 1993, Congress passed and President Bill Clinton signed an NIH reauthorization bill lifting a Reagan and Bush-era ban on government funding of research using fetal tissue transplants from induced abortions. Advocates for Parkinson's research argue that such experiments represent a transitional phase, and that alternative sources of cells for transplant, such as pig fetal tissue, will be widely available within a few years.

The Udall bill has been introduced by Henry Waxman (Democrat, California) and has 209 co-sponsors, an unusually large backing in the 435-member House. These include liberal Democrats and prominent conservatives such as Thomas DeLay (Republican, Texas), House Majority Whip, and John Kasich (Republican, Ohio), chairman of the House Budget Committee.

The bill has 54 co-sponsors in the Senate, where it was introduced by Mark Hatfield (Republican, Oregon), chairman of the Appropriations Committee. Last week, the Senate Labor and Human Resources Committee unanimously incorporated it, in modified form, into legislation reauthorizing spending on the NIH to the end of the century. As passed by the committee, the NIH Revitalization Act authorizes \$80 million for Parkinson's research in 1997.
Paul Wellstone (Democrat, Minnesota), the chief committee backer of the provision, and both of whose parents had the disease, called the committee's action "an enormous step forward". But the bill's momentum is being blocked in the House, where abortion politics appear to be playing a large role during an election year. Michael Bilirakis (Republican, Florida), chair of the subcommittee on health of the House Commerce Committee, has not taken action on the Udall bill, which was referred to his subcommittee in April

A spokesman said that Bilirakis, whose youngest brother died of the disease, is "very concerned" about the bill and "definitely supports [it]", but that a packed legislative calendar has prevented him from taking action. But others maintain that politics are behind the bill's stalled progress. Bilirakis is "essentially blocking it from getting to the floor," said Joan Samuelson, president of the Parkinson's Action Network, an advocacy group.

Waxman's spokesman Phil Schiliro called the House inaction "very unfortunate". He said "too many people in the country want this to have Congress ignore it," reflecting the fact that about 1.5 million Americans suffer from Parkinson's. Earl Hilliard (Democrat, Alabama), is gathering signatures for a letter to Commerce Committee chairman Thomas Bliley (Republican, Virginia), complaining about Bilirakis' inaction.

Parkinson's researchers are also disappointed. Abortion "is a public policy issue and shouldn't be decided in a scientific arena where scientists are seriously attempting to help patients with horrible disabilities," said Warren C. Onslow, the principal investigator on the Mount Sinai grant.

Smith's alternative bill has gained 15 cosponsors. Smith circulated a letter to House members on 12 July outlining current NIH projects involving fetal tissue transplants and urging them to switch support to his bill.

Cliff Stearns (Republican, Florida) is among several conservatives who have removed their names from the Udall bill. $\mathrm{He}$ told the House last week that he did so "due to my concerns that it allows the NIH to expand its research using tissues from aborted babies".

Zach Hall, the director of the NINDS, which funds most NIH research into Parkinson's, supported the use of fetal tissue as a transitory step in testimony last month to a subcommittee of the Senate Appropriations Committee. No-one believes that fetal tissue transplants will be carried out on a large scale in ten years, he said. "We view this as a step in the research and not as an end."

Meredith Wadman

\section{New chairman sees 'outward-looking' role for science board}

Washington. The new chairman of the US National Science Board (NSB) has promised that it will "look more outwards" from its immediate task of governing the National Science Foundation (NSF) to offer advice on key science policy questions.

Richard Zare, 56, a professor of chemistry at Stanford University, chaired his first board meeting last week. He says that during his two-year tenure he would like the board to deal with issues such as the "proper role of the federal government in research", the nature of the connection between research and development, and ways of handling international scientific collaborations.

The NSF funds most non-biomedical university research in the United States. Zare

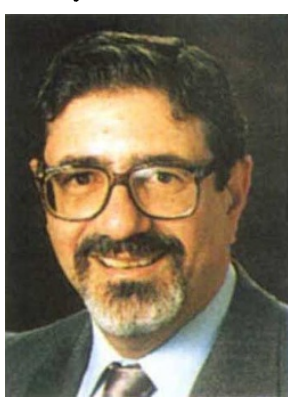

Zare: risk-aversion may have its dangers. says that the board's priority in governing the NSF will be to ensure that merit review works fairly and that the foundation allows enough emphasis on emerging disciplines.

"The question is how do you know when to stop good work in order to start better work that might fail?" he says. Zare sees a danger that agencies such as NSF may become reluctant to take risks now that money is tight. He concedes that taking the "high ground" and pursuing new work will be "politically difficult and may cost the NSF support in the Congress".

Zare says that the board will look at revising the format of Science and Engineering Indicators, the NSF's information-packed but sometimes impenetrable biennial report on the state of US research.

NSB members are appointed by US presidents to serve rolling six-year terms. The whole panel is therefore not picked by the sitting president, who usually turns instead to his own panel for advice - the President's Council of Advisors in Science and Technology, in Bill Clinton's case.

As Zare arrived in his part-time position, the NSF announced the departure of its deputy director Anne Petersen after less than two years, to join the Kellogg Foundation, a Michigan-based charity. The loss of Petersen, responsible for much of the dayto-day running of NSF, comes at a bad time for the agency, which may face severe staff cuts this autumn (see Nature 382, 7; 1996).

November's presidential election makes it unlikely that a permanent replacement will be confirmed before the beginning of next year.

Colin Macilwain 